\title{
Can Traditional Markets Became Online Market
}

\author{
Sugeng Eko Yuli Waluyo*, Mohamad Johan Efendi, Yunita Dwi Wikandari, Ahfi Nova Ashriana, Ghozali \\ Economic Faculty \\ University of Mayjend Sungkono \\ Mojokerto, Indonesia \\ *sugeng.windurejo@gmail.com, mohamadjohanefendi@gmail.com, yunitawayan6538@gmail.com, ahfinova15@gmail.com, \\ drs.ghozali1@gmail.com
}

\begin{abstract}
In this era of the coronavirus pandemic, all fields are experiencing changes. Including the world of economy and business, especially in marketing. The movements are very dynamic. A businessman must be required to have innovative creativity. These changes affect all human activities as consumers, in which consumers are an important element and need to get attention in the business world. Consumers as users of goods and services always have considerations in deciding purchases, among others in choosing a product brand, facilities and service quality. The basis for successful marketing is understanding consumer needs, therefore a company must develop an effective strategy to support attractive offerings for the target market. In this all-digital era, all consumer needs must be available and served quickly, easily accessible and obtained, clean and hygienic according to health protocols, at that time producers are also competing to immediately take this market segment and provide the best service. This study aims to determine the information literacy of changes in consumer behaviour from traditional markets affected by the Coronavirus outbreak to the online market. This research uses a literacy study method in which data is collected from libraries, reading, taking notes and processing research materials. Coronavirus has a very broad impact on the fate of traders and traditional market business actors because their turnover has dropped dramatically, getting around this problem, many traders use digital marketing applications. By cooperating with service providers between goods. this strategy is to attract potential buyers in the online market.
\end{abstract}

Keywords—traditional market, online market, coronavirus

\section{INTRODUCTION}

As is well known, since the end of 2019 the world has been rocked by a deadly virus. This virus has claimed many lives, especially medical personnel and the wider community. In addition, the impact of the coronavirus is also felt in all aspects of life, especially the economy. Many companies have closed and laid off their employees due to the lockdown. The business world has also slumped. The traditional market is empty of buyers. Consumers are busy turning to online markets. The decline in purchases in traditional markets is due to changes in consumer purchases [1]. The traditional offline channel gets the effect of selling the online channel via e-tailer [2]. In addition, the gentrification of traditional retail markets as a social implication is very detrimental to the quality of life of the population [3]. Small and informal businesses are struggling to survive amid competition from giant retailers in shopping centers [4]. Superstores run by corporate retailers pose a threat to the traditional retail market even though they have long been a center of vitality in urban areas [5]. In fact, the opportunity to enter the online market is still very possible for traditional retailers [6]. The strategy of using virtual stores has been considered by many traditional retailers or people who do not have sufficient capital to have physical stores to reach the global market [7].

\section{METHODS}

In this study, the authors used the literature review method, namely the collection of data sources by citing and reviewing theories, the findings of several scientific articles in the form of journals, books, the internet and other literature from several authors around the world related to the topic being discussed, then providing reviews and analysis of the aims and objectives of the research results. Literature reviews or also known as literature searches are used to avoid plagiarism or duplication because by searching the literature we can see previous research that has been done by other researchers. The results of this literature review will be used to identify a shift in the sales system from traditional to online markets.

\section{RESULTS}

\section{A. Business Innovation}

A market will be formed if a seller and a buyer meet and make an agreement or transaction. When buyers want the convenience of finding sellers and they are involved in a transaction that is comfortable and trustworthy, that's when the main function of the market becomes very meaningful [8]. To form a new market or reshape an existing one, a service innovation capable of making improvements is needed [9]. To make a business innovation, several effective marketing communication media are needed, for example, email, social networks, web pages, text messages, newspapers and so on [10]. 


\section{B. Customer Orientation}

Through the internet, we can find billions of potential customers, we can serve smaller and specific market segments as well as adjust offers to buyers [11]. In online purchases, online shoppers have a distinctive profile and dominant character [12]. so that we can easily seize this opportunity. There are several behavioural features of online buyers, including being in the internet environment, communicating via the internet, a demographic structure that is accessible to the internet and a motive approach to online shopping [13]. The construction of social trading, trust and online behavioural advertising were significantly able to influence purchase intention [14]. Buyers make repurchase intentions, related to online retailer satisfaction. Fostering relationships, personalization, ease of communication and assurance of customer privacy are factors that influence this [15].

\section{Online Excellence}

Consumer behaviour can be changed with the application of information technology (IT) and short message service (SMS) based on mobile commerce (m-commerce) and this increases economic efficiency [16]. In terms of price levels, menu costs and price elasticity, the internet market is more efficient than conventional markets [17]. With a few clicks, consumers can be directed by web-based sellers to go directly to their site so they can explore goods and services, of course by using online advertising [18]. So that more and more companies have started operating online in recent years [19]. In the world of education, online learning and training are cost-effective because they can cross geographic and time constraints[20]. Along with traditional media especially television, the internet can play a major role in advertising [21] because to access data globally, it has been provided by various players on the internet [22]. To increase brand trust and purchase intention, digital marketing and online advertising campaigns are more effective than traditional marketing [23] because in communication production, distribution and consumption, internet advertising brings many changes [24]. Major changes have also occurred in the book market due to the emergence of digital technology and the internet [25] and traditional environmental components have been replaced by e-sales due to the development of the internet [26].

\section{DISCUSSION}

From several references to business innovation, customer orientation and online excellence in the point results above, it can be explained that sellers in traditional markets can survive and compete, by making significant changes and improvisations and business innovations in their trading activities. Marketing must be oriented towards making it easier for customers to access the products they want to buy to achieve satisfaction and repurchase interest from loyal customers. All of that can be implemented by making a transition from traditional markets to online markets, taking into account the various advantages of the online market that have been described above.
Although in a study it is said that price formation in traditional markets is determined by the development of effective information networks and utilizing emotional sentiments from friendly social relationships to resolve competition [27], however, business people in traditional markets need to think about the possibility of moving to the online market. Or the first step taken so as not to make changes frontally is to combine traditional with online. The combination of digital marketing with traditional campaigns to achieve goals [28]. Traditional media will play complementary roles, and the internet and social media will serve as the main sources of news and information [29].

There is another study involving the role of the government. When there is a disinvestment in the market accompanied by the displacement of customers and shopkeepers, the government has an important role in regulating the urban restructuring process [30]. The government can intervene to participate in improving the economy of a region with a regulation that makes it easier for sellers and buyers to meet online to make transactions, by lowering sales taxes, for example.

According to experts, all products globally will be sold online by $40 \%$ by 2026 [31]. Because online sellers in addition to selling goods and services, they also sell value, value for convenience, comfort, security, and value for trust. Online payments are also divided into two: core value payments and value-added payments [32]. Some large companies that initially served customers manually, now they provide services online. So potential consumers simply order the goods or services they want from home, then the process will automatically serve consumer orders. A new transformation based on a better approach and higher benefits for all actors involved in the distribution process, airline companies provide services from computer reservations to global distribution systems [33]. Likewise travel companies, in the online travel and tourism market, the extreme expansion of digital technology and social networks in recent years has had a profound impact [34]. In the newspaper and print media business, there are also major changes. The existence of traditional printed newspapers could be threatened by the growing popularity of online newspapers [35] then the traditional printed newspaper company must also make adjustments so that its loyal customers do not abandon it. These online market accesses are not just the fact that they supply a fame and feedback system which helps facilitate believe but also because of the ease with which buyers find sellers [36].

Changes in this era are like an unstoppable locomotive speed. Change is not only in the scope of certain aspects of life, but all aspects experience a change, such as changes in the social, educational, legal, and so on. The term change is considered as a process. The process of change from conventional to modernity. In today's modern life, traditional markets not only have to compete with modern markets such as malls or supermarkets but also represent a formidable challenge for the traditional market itself, namely the change to the digital era. 
To overcome the competition in this modern era, traditional markets need innovation. It cannot be denied that any innovations carried out by the community and government in traditional markets will result in social change. This innovation can take advantage of technology. Technology is a tool that can help to find out how to produce the desired products, minimize a problem. Modern technology is also able to reduce barriers to interacting in people's lives. Changes in everyday life in society are influenced by developments in internet technology and the popularity of smartphones [37]. From the emergence of this technological capability, it gave birth to social and cultural subsubs. But it is also undeniable that the existence of new technology also has negative effects in several other aspects.

\section{CONCLUSION}

This study concludes that to avoid the risk of loss and even collapse of traditional markets due to decreased consumer buying interest due to the coronavirus pandemic which will end, players in traditional markets are advised to make changes. The change is to compensate for changes in market demand which are very dynamic. Changes to a better direction in terms of providing services, comfort, safety, product quality as well as time and cost-efficiency. Players in traditional markets must innovate their business, be customer-oriented, and take advantage of online facilities to increase sales and profits. This change implies that all sellers will compete to provide the best service and price to potential customers.

\section{REFERENCES}

[1] S.K. Jeong and Y.U. Ban, "Spatial Configurations for The Revitalization of a Traditional Market: The Case of Yukgeori Market in," p. 17, 2020.

[2] F. Mai, J. Zhang, R. Yang, and X. Sun, "Complexity Analysis of Pricing in a Multichannel Supply Chain with Spillovers from Online to Offline Sales," Complexity, vol. 2020, p. 17, 2020.

[3] P. Guimarães, "Exploring the impacts of gentrified traditional retail markets in Lisbon in Local Neighborhoods," Soc. Sci., vol. 8, no. 6 , 2019.

[4] MSCEC Ikadeh, "The impact of shopping center development on informal and small businesses in Lagos, Nigeria," vol. 14, no. 3, pp. 1$10,2020$.

[5] Y.M. Yi and E.N.T. The game, "What makes an old market sustainable? An empirical analysis on the economic and leisure performances of traditional retail markets in Seoul, "Sustain., vol. 10, no. 6, 2018.

[6] R. Bauerova, "Online grocery shopping acceptance: The impact on the perception of new technologies and loyalty in retailing," Cent. Eur. Bus. Rev., vol. 8, no. 3, pp. 18-34, 2019.

[7] I.Y.L. Chen, "Understanding retailers' acceptance of virtual stores," Knowl. Manag. E-Learning, vol. 2, no. 3, pp. 328-336, 2010.

[8] J. Levin, "Peer-To-Peer Markets," 2015.

[9] L.L. Berry, V. Shankar, and J.T. Parish, "Creating New Markets Through Service Innovation,” vol. 47, no. 2, p. 11, 2006.

[10] D. Schüller and K. Doubravský, "Fuzzy similarity used by microenterprises in marketing communication for sustainable development," Sustain., vol. 11, no. 19, p. 15, 2019.

[11] J. Arenas-Gaitán, B. Sanz-Altamira, and PE Ramírez-Correa, "Complexity of Understanding Consumer Behavior from the Marketing Perspective," 2019.
[12] S. Nagy, "E-commerce in Hungary: A Market Analysis," Theory, Methodol. Pract., vol. 12, no. 2, pp. 25-32, 2016.

[13] V. Svatosova, "Motivation of Online Buyer Behavior," J. Compet., vol. 5, no. 3, pp. 14-30, 2013.

[14] A.A. Ali, A. Abbass, and N. Farid, "Factors Influencing Customers' Purchase Intention in Social Commerce," vol. 10, no. 5, pp. 63-73 2020

[15] M. Mpinganjira, "Understanding online repeat purchase intentions: A relationship marketing perspective," Manag., vol. 19, no. 2, pp. 117 135, 2014.

[16] M.G. Martinsons, "Relationship-based e-commerce: theory and evidence from China," pp. 1-26, 2008.

[17] M.D. Smith, J. Bailey, and E. Brynjolfsson, "Understanding Digital Markets: Review and Assessment Understanding Digital Markets:,' 1999.

[18] D.S. Evans, "The Online Advertising Industry: Economics, Evolution, and Privacy," vol. 23, no. 3, pp. 37-60, 2009.

[19] F. Yang, Y. Wang, J. Pei, and J. Li, "Electronic markets selection in supply chain with uncertain demand and uncertain price," Math. Probl. Eng., vol. 2015, 2015.

[20] S.J. Bartley and J.H. Golek, "Evaluating the cost effectiveness of online and face-to-face instruction," Educ. Technol. Soc., vol. 7, no. 4, pp. 167 175, 2004.

[21] N.A. Adzharuddin, "Marketing Communication Through the Integration of New Media and Traditional Media: the Insights," Rev. Adm. Publica si Polit. Soc., vol. 1, no. 8, pp. 18-31, 2012.

[22] H.J. Van Miegroet, K.P. Alexander, and F. Leunissen, "Imperfect Data, Art Markets and Internet Research," Arts, vol. 8, no. 3, p. 76, 2019

[23] M. Tümer, I. Aghaei, E. Öney, and Y. Nasser, "The impact of traditional and social media marketing on customers' brand trust and purchase intentions in the Turkish airline market," vol. 1, no. 4, pp. 55-69, 2019.

[24] J. Primorac, "The Digital Advertising Gap and the Online News Industry in Croatia," 2018.

[25] C. Frunteş, "Trends and developments on the Book Market. Particularities of the Romanian market, "Bull. Transilv. Univ. Brasov. Ser. V Econ. Sci., vol. 8, no. 2, 2015.

[26] A. Tălpău, "The marketing mix in the online environment," Bull. Transilv. Univ., vol. 7, no. 2, pp. 53-58, 2014

[27] M. Purnomo, F. Otten, and H. Faust, "Indonesian Traditional Market Flexibility Amidst State Promoted Market Competition," 2018.

[28] R.D. Todor, "Blending traditional and digital marketing.," Bull. Transilv. Univ. Brasov, Ser. I Eng. Sci., vol. 9, no. 1, pp. 51-56, 2016.

[29] M.I. Seelig, "Web Economics: The Added Value of the Web for Daily Newspapers and Commercial Television Stations," vol. 3, no. 1, pp. 8196, 2011.

[30] P. Gonzalez, S and Waley, "Traditional retail markets: the new gentrification frontier ?," vol. 45, 2012.

[31] A. Barska and J. Wojciechowska-Solis, "E-consumers and local food products: A perspective for developing online shopping for local goods in Poland," Sustain., vol. 12, no. 12, 2020

[32] C. Xiang-bing and X. Kai, "An Analysis on Price Dispersion in Online Retail Market Based on the Different of the Product Levels," no. August, pp. 54-58, 2012.

[33] C.V. Pietreanu, "Analysis of traditional Global Distribution Systems vs New Distribution Capability, ”vol. 11, no. 2, pp. 239-247, 2019.

[34] T. Sjekavica, M. Žitnik, and M. Mili, "A Novelty Model Of Online Accommodation Presentation And Discovery," pp. 363-381, 2017.

[35] M. Assumpção, S. Alfinito, and B.G.A. Castro, "Consumo de Jornal Impresso e Online: Impresso é Status, Online é Facilidade," Rev. Adm. Contemp., vol. 23, no. 1, pp. 23-42, 2019

[36] S. Tadelis, "Reputation and Feedback Systems in Online Platform," p. 32, 2016.

[37] Y. Yang, Z. Li, Y. Su, S. Wu, and B. Li, "Customers as Co-creators: Antecedents of customer participation in online virtual communities," Int. J. Environ. Res. Public Health, vol. 16, no. 24, 2019 